\title{
Social Partner Agreements and Local Regulatory Legal Acts in the Labor Law of Belarus, Russia, and Ukraine
}

\author{
Kirill L. Tomashevski ${ }^{1}$, Elena A. Volk ${ }^{2}$ \\ ${ }^{1}$ Civil Law, Law of the International Institute of Labour and Social Relations, Minsk, Belarus; ${ }^{2}$ Ecology, Belarusian State University \\ of Informatics and Radio Electronics, Minsk, Belarus. \\ Email: k_tomashevski@tut.by
}

Received November 15 $5^{\text {th }}, 2010$; revised December $1^{\text {st }}, 2010$; accepted January $15^{\text {th }}, 2011$.

\begin{abstract}
The legal nature of a tariff agreement became the subject of study first by French jurists (Lambert, Deslenre, B. Reno) in the 1890s, and, since the beginning of the XXth century, by German (F. Lotmar, H. Zinzgeimer, etc.) and Russian jurists (L.S. Tal , I.S.Vojtinsky). Moreover, already in 1900 G. Zultser and F. Lotmar elaborated and published a draft Swiss law on a working tariff agreement, and in 1906 a similar draft government law was prepared in France.
\end{abstract}

Keywords: Collective Contract, Collective Agreement, Local Regulatory Legal Acts

\section{Introduction}

The legal nature of a tariff agreement became the subject of study first by French jurists (Lambert, B. Reno, etc.) in the 1890 s, and, since the beginning of the XXth century, by German (F. Lotmar, H. Zinzgeimer, etc.) and Russian jurists (L.S. Tal [1], I.S.Vojtinsky [2]). Moreover, already in 1900 G. Zultser and F. Lotmar elaborated and published a draft Swiss law on a working tariff agreement, and in 1906 a similar draft government law was prepared in France [2].

The significance of regulatory acts as sources of the internal legal order of economic entities (enterprises) capable of creating objective law was noted as far back as early XXth century by L.S. Tal [3], founder of the Russian science of labor law.

In the Soviet science of labor law, the issues concerning legal regulation of collective contracts (agreements) came under intensive study in the 1920s, particularly in the works by P.D. Kaminskaia [4], I.A. Trahtenberg [5], etc. [6]. Various Soviet labor law researchers ${ }^{1}$ devoted considerable attention to legal regulation of collective

\footnotetext{
${ }^{1}$ G.K. Moskalenko, A.E. Pasherstnik, G.I. Liah, etc.

${ }^{2}$ M.V. Lushnikova, A.F. Nurtdinova, I.O. Snigireva, S.Yu. Chucha, etc. ${ }^{3}$ A.A. Voitik, O.V. Chesalina.

${ }^{4}$ V.M. Bojko, V.I. Komarnitskiy, G.I. Chanisheva, etc.

${ }^{5}$ In this article, social partner agreements mean any collective contracts (agreements) concluded by trilateral partnership subjects (or their representatives). This terminology is also used by other authors.
}

agreements.

Some issues dealing with local legal regulation of labor relations were studied during the Soviet period in a number of monographs and dissertation theses (R.I. Kondratiev [7], etc.).

Following the disintegration of the USSR and the gaining of independence by the former Soviet Republics, the social partnership topics became increasingly important with the emergence of independent trade unions that became more active in defending the interests of workers through engaging in a social dialogue with employers with the state acting as an intermediary.

In the contemporary period, the social partnership issues have been the subject of intensive study by a number of labor law researches from Russia ${ }^{2}$, Belarus ${ }^{3}$, Ukraine $^{4}$, including, to some extent, the issues relating to the legal nature of collective agreements.

In the contemporary Russian science of labor law, local regulatory acts have been studied by G.V. Hnikin [8], M.A. Drachuk [9] and other jurisprudents. This topic has not been the subject of monographic study by Belarusian scientists in the period of independence.

At the same time, the correlation between social partner agreements ${ }^{5}[10]$ and local regulatory legal acts remains a disputable issue in the field of science, and a problem that has not been resolved in the field of legislation, which is confirmed by the differences in the legal 
regulation of the above sources of labor law in Belarus, Ukraine and Russia. This article examines the legal nature of social partner agreements and local regulatory acts, also their separation and classification. A collective contract has the two-fold character: on the one hand, as a deal (contract, obligation), and, on the other hand, as a regulatory (legal) act or a regulatory agreement. Social partner agreements have a priority over appropriate legislative acts and local regulatory legal acts, if the social partner agreement upgrades the legal status of an employee. The article contains proposals at improving the legislation of Belarus, Russia and Ukraine.

\section{Legislative Definitions of Social Partner Agreements and Local Regulatory Acts}

In Russia, the legal definitions of a collective contract and a collective agreement are provided in the Labor Code of the Russian Federation, dated 30/12/2001 (hereinafter referred to as the RF LC) [11]. Article 8 of the RF LC is entirely dedicated to local regulatory acts containing the norms of labor law though without legally defining this notion.

Following the introduction of global alterations to the RF LC in accordance with Federal Law No. 90-FZ, dated $30 / 06 / 2006$, the legal definitions of a "collective contract" ${ }^{\prime \prime}$ and a "collective agreement" underwent minimal editorial corrections. A social partner agreement retained its legal character in the RF LC remaining a legal act. It is interesting that Russian law makers refrained from defining both the collective contract and the collective agreement as regulatory legal acts. Nevertheless, the above legal definitions seem to be far from indisputable as they qualify collective contracts (agreements) as legal acts rather than regulatory agreements, which in practice may lead to confusion between such collective contracts (agreements) and employer's local acts.

Another vivid example of erroneous confusion in the legislation of the Republic of Belarus between collective contracts (agreements) and local regulatory acts is the Labor Code of the Republic of Belarus, dated 26/07/1999, (hereinafter referred to as the RB LC). According to paragraph 3, Part 1, Article 1 of the RB LC, local regulatory acts are defined as "collective contracts (agreements), internal regulations, and other regulatory acts, adopted in

\footnotetext{
${ }^{6}$ According to Part 1 , Article 40 the RF LC, a collective contract is a legal act, regulating social and labor relations at an organization or with respect to an individual entrepreneur, concluded between employees and employers represented by their proxies.

${ }^{7}$ According to Part 1, Article 45 the RF LC a collective agreement is defined as a legal act, regulating social and labor relations and establishing the general principles that regulate the economic relations associated therewith, concluded between the authorised representatives of employees and employers at the federal, interregional, regional, sectoral (intersectoral) and territorial social partnership levels within the scope of their authority.
}

accordance with the established procedure, regulating labor relations and any other relations associated therewith with respect to a specific employer." In our view, this definition is erroneous as by their legal nature collective contracts (agreements) are regulatory agreements rather than regulatory acts. This gross terminological error spilled over into many other norms contained in the RB LC (e.g., Articles 7, 55, 194).

Article 7 of the RB LC classifies, along with the labor legislation, any collective contracts (agreements) and any other local regulatory legal acts, concluded and adopted under the existing legislation, as the sources of regulation of labor relations and other relations associated therewith. Part 2, Article 7 of the RB LC contains an important provision stating that local regulatory acts introducing any conditions degrading the position of employees as compared to the existing labor legislation are considered null and void. A similar provision is provided in Part 2, Article 194 of the LC. From these regulations, one may conclude that local regulatory legal acts may only upgrade the position of the employed personnel as compared to the existing legislation (the so called in favorem principle) but may not degrade it.

The definitions that seem to be disputable include also those of a collective contract and a collective agreement given in Article $361^{8}$ and Article $358^{9}$ of the RB LC. In its turn, paragraph 12, Part 1, Article 1 of the Law of the Republic of Belarus No. 361-3 entitled "On Regulatory Legal Acts of the Republic of Belarus," dated 10/01/2000, defines a regulatory legal act ${ }^{10}$.

The above legal definitions provided in the the RB LC seem to contain the same defect as the formulations given in the RF LC, which may be explained by the reciprocal influence of the above codes in the course of their elaboration and adoption. The only difference is that Russian law makers define the social partner agreements as legal acts while their Belarusian counterparts define the same agreements as regulatory legal acts. In our view, the error of both the Russian and Belarusian law makers is that collective contracts and agreements are not regulatory (legal) acts as they have a different legal nature, which will be substantiated below.

\footnotetext{
${ }^{8} \mathrm{~A}$ collective contract is defined as a local regulatory legal act regulating labor relations and social and economic relations between an employer and employees.

${ }^{9}$ An agreement is a regulatory act containing the obligations of the parties concerning the regulation of relations in the social and labor sphere at the level of a specific occupation, sector, territory.

${ }^{10} \mathrm{~A}$ regulatory legal act is a formal document of a standard format adopted (issued) within the scope of authority of an authorised state body (an official) or in a referendum with the observation of the procedure, established in accordance with the legislation of the Republic of Belarus, containing the rules of conduct mandatory for observation by all parties concerned, designed for a specific group of persons and regular application.
} 
Although by adopting Law No. 272-3, dated 20/07/2007, Belarusian law makers eliminated the discrepancy in terminology between the RB LC and the Law of the Republic of Belarus No. 361-3 entitled "On Regulatory Legal Acts of the Republic of Belarus," dated 10/01/2000 (previously both the RB LC and the RF LC used the category of a "local regulatory act"), we believe that this problem has not been completely resolved. At present a large number of local acts such as individual local acts or mixed local acts, including both the regulatory precepts and the individual law enforcement provisions (e.g., staffing tables, leave schedules, shift schedules, etc.). It is evident that these local acts are not covered by the term "a local regulatory legal act," but nevertheless require legal regulation. In this connection, it would be legally justified to use in the scientific terminology and, in the future, in the legislation, a broader notion of a "local act" which would incorporate three types of acts that may be adopted by an employer within the framework of his regulatory authority, including regulatory (legal), individual, and mixed acts.

Referring to the Ukrainian legislation, it may be noted that the Code of Labor Laws of Ukraine (1971) (hereinafter referred to as the CLL that is a revised copy of the Soviet code does not contain a legal definition of a collective contract though in Article 10 it defines the purpose of the conclusion of a collective contract as the regulation of production, labor, social and economic relations and the coordination of the interests of employees, owners, and the bodies authorized thereby. The CLL of Ukraine and the Law of Ukraine entitled "On Collective Contracts and Agreements" (1993) contain no definitions of social partner agreements [12]. The CLL of Ukraine also contain no general norms dealing with local regulatory legal acts though some types of such local regulatory legal acts are referred to throughout the text (leave schedules (Article 79), internal labor schedules (Article 142), etc.).

At present the Government of Ukraine has drafted the Labor Code of Ukraine (hereinafter referred to as the draft LC of Ukraine) whose provisions are also of scientific interest for the purposes of comparative analysis. The draft CL of Ukraine contains Chapter 2 entitled "Regulatory Legal and Other Acts that Regulate Labor Relations" including 8 articles. For the purposes of this paper, let us dwell only on two articles of this chapter (Articles 11 and 12) that, in our view, were drafted, to a certain degree, under the influence of Article 5 of the RF LC. Article 11 of the draft CL of Ukraine, introducing a system of regulatory legal acts and other acts governing the regulation of labor relations, in addition to labor legislation acts, includes general, sectoral, and territorial agreements, collective and labor agreements, and em- ployer's regulatory acts.

Article 13 of the CL of Ukraine deals such source of labor law as the employer's regulatory acts (being, to a considerable degree, similar to Article 8 of the RF CL). An important provision ensuring the interests of employees is the regulation stating that the employer's regulatory acts must not contravene any legislative acts, agreements, a collective contract, or the constituent documents of an employer having the status of a legal person. At the same time, it seems to be erroneous to confuse in i.1, Article 13 of the draft LC of Ukraine between employer's local acts and organisational and administrative documents (orders, directives and resolutions).

\section{The Problem of Confusion Between Social Partner Agreements and Local Acts}

It has to be stated that local regulatory acts are often confused in educational and scientific literature with collective agreements [13], although they have different legal nature and only a few similar features associated with their sphere of application. There are also other differences between social partner agreements and local regulatory legal acts [14]. G.V. Khnykin emphasises that "a collective agreement and other local regulatory acts containing the norms of labor law are two different models used to regulate labor relations at the level of an organisation" [15]. At the same time, the opinion of the same scientist concerning the conventional character of the division of local sources into regulatory agreements and local regulatory acts does not seem to be quite consistent [15]. His argument concerning the inclusion in practical application of individual local acts as appendices to a collective contract also does not seem to be very convincing as a local act included in a collective agreement as its constituent part ceases to be from such time an act of the employer's administrative authority and "turns" into a collective contract component with all the ensuing consequences (in particular, alterations and amendments are introduced using a negotiation and registration procedure). In this case, it would be more correct to consider a possible transformation of the form of a local norm of labor law (a collective agreement as a type of a local regulatory agreement becomes such form instead of a local regulatory legal act). Thus when considering the correlation between the above sources of labor law having a different legal nature, they should not be confused by erroneously classifying collective contracts as a variety of legal acts [16]. It is important that the precision of legal definitions should be not only taken into account in scientific research and for educational purposes but also consistently applied in labor legislation.

Let us note that already in the 1920s the concept of the "two-fold character" and "mixed nature" of a collective 
agreement (containing both regulatory and liability provisions) was introduced in the theory of the western labor law and laid down in German legislation [4]. Also, at the beginning of the XXth century, L.S. Tal, founder of the Russian labor law wrote about regulatory agreements referring, as an example, to collective contracts of double-fold character [17]. It may be noted that even the Soviet labor law researchers considered labor collective agreements to be a certain variety of labor law sources [18].

The concept of the two-fold character of a collective contract has become by now well-established in the national science of labor law: on the one hand, as a deal (contract, obligation), and, on the other hand, as a regulatory (legal) act or a regulatory agreement [19]. Also, the legal nature of agreements is interpreted individually depending on the type and the level of adoption thereof: "General, interregional, and regional collective agreements determine the general principles of the regulation of social and labor relations." They are of a framework nature while sectoral (intersectoral) agreements and territorial agreements establish the common labor remuneration conditions, guarantees, compensations, and benefits for personnel. We believe that by their nature such agreements seem to be closer to collective contracts. Therefore, we determine the legal force of these collective agreements on the basis of their "mixed nature" [20].

Let us consider several contemporary approaches towards defining social partner agreements substantiated by Russian and Belarusian labor law researchers.

L. Yu. Bugrov, a Russian labor law researcher, substantiated and formulated the definition of collective agreements as "legal acts regulating the relations concerning the employees' labor and amenity conditions; signed by the representatives of the employers' associations, the associations of labor collectives (the collectives of workers) and the state bodies or local self-government bodies, corresponding to the level of the act being signed, after reaching an agreement concerning the content and the form of the given act; covering more than one labor collective" [21]. The defects that may be found in this definition include, firstly, the use of the term "legal acts" that fails to reflect accurately the legal nature of these sources and, secondly, the determination of the scope of application by pointing to "more than one labor collective" as such definition results in confusion between collective agreements and global collective contracts, including those concluded within the framework of transnational corporations, that may also cover a number of labor collectives.

O.V. Chesalina, a Belarusian researcher, proposed a rather precise definition of a collective contract and a collective agreement emphasising their two-fold legal character and a special contractual procedure for their adoption [18]. In our view, these definitions would become more precise if the special contractual adoption procedure had been made more specific by referring to collective negotiations preceding the conclusion of collective contracts (agreements).

The authors of a collective monograph published in Russia defined the agreements in the sphere of social partnership as "a category of legal acts covering a group of specific contracts in the sphere of labor law establishing the common principles of the regulation of social and labor relations and the economic relations associated therewith" [22]. This definition has the drawback of confusing various sources of law (legal acts, agreements). In addition, it may be interpreted as covering not only agreements but also collective contracts that, as a rule, do not establish the general principles of the regulation of social and labor relations. Such principles are set forth in international treaties and other documents, the "general provisions" of labor codes, and, to a lesser extent, in a general agreement, and very seldom in tariff and local agreements.

E.R. Voronkova, a Russian author, defines a collective contract as "a comprehensive act containing legal norms and the obligations of the parties in the sphere of labor, civil, housing, ecological, and social welfare law" [23]. The definition proposed by E.R. Voronkova may seem to have certain merits indicating the comprehensive nature of a collective contract incorporating legal norms and obligations pertaining to various sectors. At the same time, it would be more appropriate to replace the latter part with a reference to the "social and labor sphere" as it is difficult to embrace all possible social relations falling under the subject of collective contractual regulation using a closed list. For example, the obligations concerning the organisation of cultural and social activities for personnel at leisure time and the holding of sports events are not covered by the above definition.

One should agree with the opinion of A.M. Lushnikov and M.V. Lushnikova, taking into account the emerging practice of concluding general agreements, that these contracts are usually of a framework nature. At the same time, such general agreement does not completely lose the legal nature of a regulatory legal agreement as it is drafted on the basis of the agreement achieved by three parties that discuss and analyse the draft general agreement prior to its signature. Sometimes directly applicable laws are included even in general agreements, though such cases are rather exceptions to the general rule. For example, i.45 of the General Agreement Between the Government of the Republic of Belarus, the Employers' Republican Associations, and the Trade Unions for the Period of 2009-2010, in addition to various parameters of 
the economic policy, remuneration of labor, employment guarantees, protection of labor, and social partnership, include the recommendatory norms on the inclusion in tariff and local agreements of a number of provisions, concerning, among other things, the contractual employment system.

\section{Addressing a Problem through Separating Social Partner Agreements and Local Acts}

It is generally accepted in the general legal theory to identify regulatory legal acts and contracts having regulatory content or regulatory agreements as independent sources of law [24].

In our view, the principal differences between social partner agreements and local regulatory acts are as follows:

- while collective contracts and collective agreements are the result of collective negotiations and the coordinated expression of will by a number of social partnership subjects (employees, employers, and state bodies in trilateral agreements), local regulatory acts are always the result of the expression of will by a single person i.e. an employer (owner), and the expression of his regulatory authority. In this case, the procedure for obtaining approval from or notification of the trade unions does not transform these acts into social partner agreements as the participation of a trade union is of secondary importance; in these cases an act is also adopted unilaterally;

- by definition, local regulatory acts regulate relations at the level of a specific employer (for the sole exception of corporate acts at transnational corporations). With respect to this feature, local regulatory acts have a certain similarity with collective agreements, though the same feature distinguish them from labor law acts and collective agreements, covering a broader scope of application beyond the limits of an individual organisation;

- a local regulatory legal act contains legal regulations, individual regulations of conduct to be observed by the persons falling within the scope of application of such act. A collective contract and a collective agreement contain both regulatory and liability, informational, and organisational terms. The regulatory provisions of a collective agreement are the local legal regulations established by the parties within the scope of their authority. Regulatory provisions are usually used in two possible situations: firstly, when there is a clear gap in the legislation and overcoming it by means of collective negotiations would not contravene the general principles of law and the existing legislation; secondly, when the general provisions of the legislation allow for further concretization of the provisions contained therein relative to the specific features of the given organisation (an individual subdivision). The liability terms of a collective agreement determine the obligations of the parties (or their representatives) with respect to the execution of certain actions. They comprise the specific, clearly cut obligations of the parties with the indication of the periods set and the individual implementors responsible for the execution thereof. These conditions are valid until they are fulfilled and terminated upon their execution. The informational provisions reproduce the norms of labor law and general, sectoral, and local agreements. The parties drafting a collective agreement should not overload its text with the provisions that do not bear a regulatory burden. The informational terms should ensure the integrity of the content of a collective agreement with respect to a specific issue. If an agreement contains the informational terms alone, it should not be recognised as concluded [9]. The organisational provisions are concerned with the regulation of the procedure for concluding, altering, and terminating a collective agreement (the terms concerning the period of validity of a collective agreement, control over its execution, the procedure for introducing alterations and amendments, the liability for a failure to comply with or fulfil a collective agreement);

- local regulatory acts differ from collective agreements in the scope of applications with respect to the number of persons as the former are universally applicable with respect to all employees of the given employer regardless of their membership in a trade union while collective agreements cover, by a general rule, the employees who are members of a trade union in whose name such collective agreements have been concluded. Furthermore, there are local regulatory acts of general application, covering the territory of the entire organisation (e.g. a staffing table), of special application, covering only the specific categories of employees (a regulation on a structural subdivision), or those regulating specific aspects of labor relations (a regulation on a competitive election);

- a collective contract (agreement) becomes effective from the time of signature or from the date set by the parties, which is specified in Part 2, Article 367 of the RB LC. Also, at the stage of putting into force local regulatory acts, it is necessary to determine the time of and the procedure for putting them into force, as well as the time of the termination of the validity of the local act that has been previously used to regulate the respective contractual relations. It is also necessary to establish the procedure for informing the employees both of the introduction of a local regulatory legal act and of its content. These provisions may be included both in the last section of the local regulatory legal act and in a separate order (directive) issued by an employer. Besides, unlike a local regulatory legal act, a collective agreement is subject to mandatory registration with a local executive or administra- 
tive body. Such registration is obtained using a notification registration procedure both in Belarus and Russia.

There are several regulations to be complied with when putting into force local regulatory legal acts. Firstly, an approved local regulatory legal act may be put into force only after implementing the procedure for informing the affected employees of its content. Secondly, pursuant to Article 32 of the RB LC, any acts altering the substantial labor conditions of employees may be put into force not earlier that one month after informing the employees of its content (unless otherwise is provided for by the existing legislation). Thirdly, if a local act contains the regulations providing for performing the training, briefing, and knowledge examination procedures, such act may be put into force only after the required training, briefing, and knowledge examination procedures have been performed. An employer must inform employees of the existing collective contract, though the legislation sets no specific periods for providing such information [25].

There are also other differences between social partner agreements and local regulatory acts. It is important not only to take account of these differences and the accuracy of legal definitions in scientific research and for educational purposes but also to consistently apply this approach in labor law.

The problem of correlation between social partner agreements and subordinate regulatory legal acts was first posed by A.Ya. Petrov [26], a labor law researcher who did not, though, proposed any solution. Let us attempt to propose a solution to this problem on the basis of the RB LC.

Taking into account the above theoretical provisions and the social partnership character of collective contracts (agreements), the level at which they are concluded, and based on the systemic interpretation of i. 2, Article 2, Articles 7, 358, 359, 362 and 364, of the RB LC, one may draw the following conclusions concerning the correlation of social partner agreements with legislative acts and local regulatory legal acts:

A general agreement has a priority over the resolutions of the Council of Ministers of the Republic of Belarus and the acts (agreements) of a lower legal force;

a tariff agreement has a priority over the resolutions of the ministries and state committees and the resolutions of the local state bodies;

a local agreement has a priority over the resolutions of the local state bodies;

a collective contract has a priority over local regulatory legal acts, if the appropriate social partner agreement upgrades the legal status of an employee.

The principal arguments in favour of such hierarchy of social partner agreements and their correlation with subordinate and local regulatory legal acts are as follows:
- as a social partner agreement includes two or three parties, a regulation or an obligation may not be altered or repealed at the initiative of one of the parties (even if such a party is a state body; in fact, a state body may reverse the regulation that it adopted before by concluding a respective social partner agreement);

- the provisions of a social partner agreement combine the interests of two or three parties while a local regulatory legal act is an expression of will of only one of the parties to a social partner agreement;

- the systemic interpretation of Part 2, Article 362 of the RB LC ("A general agreement is used as a basis for tariff and local agreements, and collective contracts") and Part 1, Article 364 of the RB LC ("the content of a collective agreement is determined by the parties in accordance with the general, tariff, and local agreements...”) leads to a conclusion that the general agreement, taking into account the level of authority and the competence of the parties thereto, has a higher legal force than all other social partner agreements, though the latter may alter the provisions of the general agreement to upgrade the legal status of an employee. Tariff agreements have the same correlation with local agreements and a collective agreement, and local agreements have the same correlation with a collective agreement.

As a proposal aimed at improving the legislation, it may be recommended to make a number of alterations to the RF LC and the RB LC to define a collective agreement as a local regulatory act and the agreement as a regulatory contract and to consistently differentiate these social partner agreements from local regulatory acts. It should be noted that the notions of a "contract" and a an "agreement" as used herein are synonymous. When finalizing and adopting the Labor Code of Ukraine it would also necessary to take into account the proposals for amending the legal terminology. We believe that the proposals made in this article may also be of interest to foreign labor law experts from the viewpoint of comparative law.

On the basis of the above-said, we propose the author's definitions of the notions of "a collective agreement", "an agreement", and "a local regulatory legal act," reflecting more accurately the two-fold legal nature of social partner agreements and their difference from the employer's local acts, that might be taken into account by the law makers involved in improving the provisions of labor law.

A collective contract is a bilateral local regulatory legal act, concluded on the basis of the results of the collective negotiations between an employer (employers) and employees, represented by the respective representative bodies, outlining legal norms and mutual obligations of the parties in the social and labor sphere at the level of 
a specific organisation (its individual subdivision) or within the framework of a group of organizations.

A local regulatory legal act is a document, adopted individually by an employer taking into account the opinion of or by agreement with the employees' representative body, containing the local legal norms regulating labor relations and the relations associated therewith.

An agreement is a trilateral regulatory legal contract, concluded on the basis of the results of the collective negotiations between an employer (the associations of employers), employees (the associations of employees), and the state, represented by the respective representative state bodies, outlining legal norms and mutual obligations of the parties in the social and labor sphere at the level of a specific occupation, sector, or territory.

\section{Classification of Social Partner Agreements and Employer's Local Acts}

The existing labor legislations of Belarus and Ukraine have similar systems of social partner agreements including general agreements (at the republican level), sectoral agreements in Ukraine, tariff agreements in Belarus (at the sectoral level) and territorial agreements in Ukraine, local agreements (at the local level), a collective agreement (at the level of a specific organization or its individual subdivision).

The Russian Federation with its federal state territorial structure has the most ramified system of social partner agreements including two more types of agreements i.e. regional and interregional agreements (at the level of one or more federation subjects). Besides, Part 10, Article 45 of the RF LC allows the conclusion of other agreements that may be signed at any other level of social partnership to address the individual spheres of social and labor relations and other relations directly associated therewith.

Depending on their content, social partner agreements may be divided into general agreements and special agreements. The first group of agreements, dealing with general issues, contains provisions relating to various aspects of social and labor relations. Special agreements regulate relations in a specific sphere such as labor safety, occupational training, etc. [27]. General agreements are used mostly in Belarus, Russia, and Ukraine while special agreements are more often used in the EU members states and the USA.

Under the conditions of globalisation and integration of countries, national economies, and legal systems taking place in the XXIst century, it would be useful to divide social partner agreements into international, transnational, and national agreements. International social partner agreements may include the ILO conventions adopted on a tripartite basis and trilateral agreements concluded between federations and confederations of trade unions and employers and governments on the interstate level (e.g. such agreements exist within the framework of the EU). Transnational agreements may include a global collective agreement, concluded with the participation of a large number of large companies from various regions of the world, and collective agreements, concluded within the framework of transnational corporations, holdings, financial and industrial groups with trade unions, applied simultaneously in various organisations and subdivisions located in various countries. The examples of national social partner agreements have been provided above.

Referring to the classification of local regulatory legal acts, it should be noted that neither labor legislation nor any other branches of the legislations of Belarus, Russia, or Ukraine contain a closed list of such acts. For example, the labor legislation of Belarus contains only an approximate list of local acts (including local regulatory legal acts) dealing with internal labor regulations.

The grammatical and logical interpretation of Article 194 of the RB LC (including the alterations and amendments introduced by Law No.272-3, dated 20/07/2007) identifies three groups of local and social partner sources of labor law dealing with internal labor regulations:

1) social partner agreements ( a collective agreement, an agreement);

2) local regulatory legal acts (internal labor regulations (hereinafter referred to as ILR); labor protection and labor safety regulations and instructions, etc.);

3) other local acts (a staffing table, job descriptions, work (shift) schedules, leave schedules).

Thus the existing law contains a non-exhaustive list of local regulatory legal acts and, therefore, does not limit an employer from adopting within the scope of his regulatory authority any other local acts unlisted in the existing legislation.

As is seen from the above list, the local regulatory legal acts used in the sphere of labor are rather diverse, which necessitates their classification. Such classification has both a theoretical and large practical importance allowing the subject of local regulation to be correctly separated in relevant acts so as to avoid duplication and discrepancies between them.

Thus, we can identify the following types of local acts:

1) on the basis of the subject of local regulation:

- local regulatory legal acts dealing with general employment issues covering various groups of labor relations and the relations associated therewith (an organisation's charter, ILR, a regulation on personnel, a regulation on the operation of a branch, etc.);

- local acts dealing with special employment issues covering specific groups of employees (regulations on recruitment of administrative personnel, job descriptions, 
working instructions) or regulating individual aspects of labor relations and the relations associated herewith (a staffing table, regulations on remuneration of labor, a regulation on the operation of a branch, etc.);

2) on the basis of the sphere of application:

- Local regulatory acts covering several legal persons. It is a rather rare group of local acts adopted at concerns, holdings, transnational corporations that may include local acts dealing with the issues of a general and special nature;

- Local acts covering a single legal entity as a whole. These documents include practically all above internal employment acts and regulations on remuneration of labor and bonus payment and sometimes a staffing table;

- local regulatory acts covering individual subdivisions within the framework of a legal person (regulations on the operation of branches, representation offices, other structural subdivisions);

3) on the basis of the period of validity:

- local regulatory acts adopted for an indefinite period (ILR, regulations on remuneration of labor and bonus payment, job descriptions). As the period validity these acts is usually not limited, they remain valid till new local acts dealing with the same issues are adopted;

- local acts adopted for a definite period (leave schedules, shift schedules, sometimes, staffing tables);

4) depending on the types of procedures used in adopting an act $^{11}[28]$ :

- individually adopted acts, i.e. the acts adopted directly by an employer without the participation of the employees' representative bodies (e.g. job descriptions and working instructions, regulations on personnel):

- negotiated acts, i.e. the acts adopted by an employer by negotiations with a trade union (e.g. work and shift schedules, a regulation on nonstandard working time schedules, leave schedules);

5) depending on the existence of legislative regulation of a respective local act:

- listed acts, i.e. the acts that can be adopted under the existing LC or any other labor legislation act (e.g. ILR, leave schedules, job descriptions);

- unlisted acts, i.e. the acts developed in the course of the practical application of law or the acts designed by an employer on a one-time basis within the scope of his regulatory authority. For example, such acts may include a regulation on personnel, a regulation on the financial stimulation of employees.

There are also other classifications of local acts. G.V. Khnykin identifies local acts on the basis of their legal status: individually adopted acts; social partner and

\footnotetext{
${ }^{11}$ It should be noted that the type of combined local acts proposed by the author seems to be redundant as collective agreements, as mentioned above, are not local regulatory legal acts.
}

corporate local acts; on the basis of their content: material an procedural acts; on the basis of their form of expression: 1) contracts, agreements; 2) by-laws, regulations; 3) rules; 4) instructions, etc. [14].

V.A. Drachuk proposes to differentiate between local regulatory labor law acts and local regulatory corporate acts. According to this author, the latter "belong to the sphere of application of civil, administrative, and constitutional law" [9]. In our view, this classification is not sufficiently substantiated. Firstly, the notion of "corporate law" is an abstract term embracing the legal norms relating mostly to civil law and economic legislation [29]. As the term "corporation" borrowed from the AngloAmerican legal family is rather rarely used in the civil legislation of Belarus and Russia, it would be more correct to consider civil legal or economic legal acts. Secondly, this classification becomes meaningless with respect to the charters (by-laws) of legal persons containing both the civil legal regulations and the norms of labor law as these local acts may be included in both proposed groups. Probably, the author should have added a third group - mixed local acts containing the norms of differing sectoral origin.

In the RB LC, the general provisions relating to local regulatory legal acts are contained in several separate norms (paragraph 3, Article 1, Parts 2 and 3, Article 7), whereas the RF LC contains Article 8 including the general norms regulating local law-making procedures. A similar approach is used in Article 13 of the draft LC of Ukraine. A detailed analysis of specific types of local regulatory legal acts let alone local individual acts is beyond the scope of this article. Also, this topic has been the subject of a number of scientific, educational, and practical publications [30].

\section{Conclusions}

In the future, the law-makers of Belarus, Russia, and Ukraine should apply a more consistent approach to defining the notion of local acts (including local regulatory legal acts) without confusing them with social partner relations, and regulate more specifically both the general issues of the local law-making process and the application of special procedures for adopting, altering, and terminating individual local acts.

\section{REFERENCES}

[1] L. S. Tal, "Tariff (Collective) Agreement as Institute of Civil Law," St. Petersburg, 1909, pp. 54

[2] I. S. Vojtinsky, "Collective Agreements on Conditions of Work (Tariff Labor Law) as a Problem of Legislation," St. Petersburg, 1911.

[3] L. S. Tal, "Labor law. Civil Research," Moscow, 2006, pp. 444-446 (previous issues: Vol. 1 - 1911 and Vol. 2 - 
1918).

[4] P. D. Kaminskaia, "Studies of Labor Law", Moscow, 1927, pp. 37-97.

[5] I. A. Trahtenberg, "Collective Agreement $/ 5^{\text {th }}$ issue," Moscow, 1927.

[6] A. M.Lushnikov, M. V Lushnikova, "The Course of Labor Law in 2 volumes," V. I Historical Legal Introduction. Common Part. Collective Agreement Law: Course, Moscow, 2003. pp. 346-353.

[7] R. I. Kondratiev, "Local Norms of Labor Law and Financial Stimulation," Lvov, 1973. pp. 152.

[8] G. V. Hnikin "Local Regulatory Acts of Labor Law," Ivanovo, 2004. pp. 260.

[9] M. A. Drachuk, "Local Regulatory Acts of Organizations," Omsk, 2008, pp. 316.

[10] A. A. Voitik, "The Role of Social Partner Agreements in Reinforcement of Employee's Rights Protection Working on Labor Contracts/“Lawyer,"2005, No. 9, pp. 83-86.

[11] "Labor Code of the Russian Federation (with changes and additions, dated 30/06/2006),"Moscow, 2006, p. 271.

[12] "Labor Legislations of the Ukraine/Compiler I.V. Zub," Kiev," 2003, pp. 168-176.

[13] V. I. Semenkov, V. N. Artemova, G. A. Vasilevich, et al.,. "Labor Law Course," Minsk, 2002. pp. 85, 543-546; A. U. Babaskin, U. V. Baranuk, et al., "Labor Law of the Ukraine: Academician Course: Manual," Kiev, 2004. p. 74; "Labor Law of the Russia: Course," Under edition A.M. Kurennoi, Moscow, 2004, pp. 139.

[14] G. V. Hnikin "Local Regulatory Acts of Labor Law," Ivanovo, 2004, p. 102.

[15] G. V. Hnikin "Confusion of Collective Agreements and Local Regulatory Acts of Employer/Modern Tendencies in Evolution of Labor Law and Law of Social Welfare: Articles of International Scientific Practical Conference," Under edition K. N. Gusov, Moscow, 2007. pp. 256.

[16] I. A. Smirnova, "The Place of Collective Agreement in the System of Acts Regulating Labor Relations of Public Health Services/Modern Tendencies in Evolution of Labor Law and Law of Social Welfare: Articles of International Scientific Practical Conference," Under edition K.N. Gusov, Moscow, 2007. pp. 243.

[17] L. S. Tal, "Studies of Industrial Law," Moscow, 1916. pp. 43.

[18] V. M. Dogadov, "Studies of Labor Law," Moscow, 1927. pp. 23.
[19] O. V. Chesalina, "Collective Contracts and Agreements in Belarus, Russia and Poland: Comparative Legal Analysis: Abstract... Candidate of Law/The National Academy of Science of Belarus," Minsk, 2002. pp. 5; S. U. Chucha, "Social Partnership in Labor Sphere: Formation and Prospects of Evolution of Legal Regulation in the Russian Federation: Monograph," Omsk, 2005, pp. 76.

[20] A. M. Lushnikov, A. M. Lushnikov, M. V. Lushnikova, N. N. Tarusina, "Contracts in the Sphere of Family, Labor and Social Service (Civil Research): Course," Yaroslavl, 2008. pp. 295.

[21] L. U. Bugrov, "The Notion and Classification of Collective Agreements in Russian Labor Law/State and Law," No. 1, 2002, pp. 39-40.

[22] K. N. Gusov, et al., "Corporative Agreements in the Sphere of Social Labor Relations," Editor-in-chief K.D. Krilov, Moscow, 2005, pp. 15.

[23] E. R. Voronkova, Chapter 4 "Forms of Labor Law" in the book "Modern Labor Law (The Experience of Labor Legal Comparison)," Under general edition V.M. Lebedev, Moscow, 2007, pp. 160.

[24] "Common Theory of State and Law. Academician course in 2 volumes," Under general addition M. N. Marchenko, Vol. 2, "The Theory of Law," Moscow, 1998, pp. 141, 151-152; V. S. Nersesianc Common, "Theory of State and Law. Course for Legal Institutes of Higher Education and Faculties," Moscow, 1999, pp. 402, 413-414; M. N. Marchenko "The Legal Sources: Course," Moscow, 2005, pp. 283-297.

[25] O. Chesalina, "The Notion of Collective Agreement and its Legal Nature/The library of journal 'Lawyer. Law' and Business," 2007, No. 1, pp. 103-106.

[26] A. Petrov, "Hierarchy and System of Sources of Russian Labor Law/Issues of labor law," 2007, No. 8, pp. 13.

[27] M. N. Marchenko, "The Legal Sources: Course," Moscow, 2005, pp. 291-292.

[28] G. V. Hnikin, "Local Source of Russian Labor Law: Theory and Practice of Use: Abstract... doctor of legal science; specialty 12.00.05," Moscow, 2005, pp. 13-14.

[29] "Juridical Encyclopedia," Under addition V.E. Krutskih, Moscow, 2004, pp. 187.

[30] "Internal Documents of the Organization in the Sphere of Labor/The library of journal 'Lawyer'. Law and Business," No. 4, 2007, pp. 25-103; V. M. Lebedev, T. M. Fahrutdinova, I. V. Chernisheva, "The Internal Labor Rules in Organization," Moscow, 2008, pp. 127. 